\title{
Yoğun Bakım Hemşirelerinin Duygusal Emek ve Genel Sağlık Durumları Arasındaki İlişkinin İncelenmesi $\infty$
}

\author{
Altun BAKSi ${ }^{1}$, Aylin DURMAZ EDEER ${ }^{2}$
}

\section{öz}

Amaç: Yoğun bakım hemşirelerinde duygusal emeğin yordayıcısı olarak genel sağlık, sosyo-demografik ve mesleğe ilişkin bazı özelliklerin incelenmesidir.

Gereç ve Yöntem: Bu çalışma kesitsel ve ilişkisel tipte tanımlayıcı bir araştırmadır. Araştırma, Türkiye'nin batısında ve güneydoğusunda yer alan iki üniversite hastanesinde Temmuz-Aralık 2018 tarihleri arasında yürütülmüştür. Araştırmanın örneklemini yoğun bakım birimlerinde çalışan toplam 152 yoğun bakım hemşiresi oluşturmuştur. Araştırma için etik kuruldan, ölçeğin uyarlamasını yapan yazarlardan, kurumlardan ve hemşirelerden izin alınmıştır. Veriler sayı, yüzde, ortalama, korelasyon ve regresyon analizi ile değerlendirilmiştir.

Bulgular: Yoğun bakım hemşirelerinin yaş ortalaması $30.28 \pm 5.35$, \%68.4'ü kadın, \%53.3'ü mesleğini "orta düzeyde" sevdiğini ve sorumlu olunan/bakım verilen hasta sayısının ortalama $5.05( \pm 2.95)$ olduğu saptanmıştır. Hemşirelerde derinlemesine davranış alt boyutu incelendiğinde mesleği sevme durumunun (Evet) $(\beta=0.185$, $p<0.05$ ) anlamlı yordayıcı olduğu saptanmıştır. Yüzeysel davranış alt boyutu incelendiğinde, mesleği sevme durumu (Evet) ( $\beta=0.298$, $p<0.001)$ ve ekonomik durum algısının $(\beta=0.211, p<0.05)$ anlamlı yordayıcı olduğu saptanmıştır.

Sonuç: Bu çalışmada yoğun bakım hemşirelerinde genel sağlık durumunun duygusal emek için anlamlı yordayıcı olmadığı saptanmıştır. Hemşirelerin mesleği sevme düzeyi arttıkça duygusal emeğin alt boyutları olan "derinlemesine ve yüzeysel davranışın" arttığı saptanmıştır. Kurum yöneticileri hemşirelerin duygusal emek sürecini daha iyi yönetebilmesi için destek vermeli ve uygun klinik ortam oluşturulmalıdır. Yine hemşirelerin mesleklerini sevmesi için gerekli stratejilerin geliştirilmesi önerilmektedir.

Anahtar kelimeler: Duygusal emek, hemşire, sağlık, yoğun bakım üniteleri.

\begin{abstract}
Investigation of the Relationship Between Emotional Labor and General Health Status of Intensive Care Nurses Aim: This study was conducted to investigate general health, sociodemographic characteristics and some profession-related characteristics in intensive care nurses as a predictor of emotional labor.

Material and Methods: This study is a cross-sectional and relational study. The study was carried out in two university hospitals located in the west and southeast of Turkey between July and December 2018. The sample of the study consisted of a total of 152 intensive care nurses working in intensive care units. Permissions for the study were obtained from the ethics committee and the university hospitals. Data were analysed with number, percentage, mean, correlation and regression analysis.

Results: It was determined that the average age of intensive care nurses was $30.28 \pm 5.35,68.4 \%$ were women, $53.3 \%$ loved their profession at a "moderate level" and the average number of patients who were responsible/cared for was $5.05( \pm 2.95)$. When the in-depth behavior sub-dimension was examined in nurses, it was found that the state of liking the profession (Yes) $(\beta=0.185$, $p<0.05$ ) was a significant predictor. When the superficial behavior sub-dimension was examined, it was determined that the state of liking the profession (Yes) $(\beta=0.298, p<0.001)$ and the perception of economic status $(\beta=0.211, p<0.05)$ were significant predictors. Conclusion: In the study, it was determined that general state of health was not a significant predictor of emotional labor in intensive care nurses. It was found that as the nurses' level of liking the profession increased, "in-depth and superficial behavior", which are the sub-dimensions of emotional labor, increased. Institution managers should provide support and create an appropriate clinical environment for nurses to manage the process of emotional labor better. In addition, it is recommended that necessary strategies be developed for nurses to love their professions.
\end{abstract}

Keywords: Emotional labor, health, intensive care units, nurse.

\footnotetext{
1Dr. Öğr. Üyesi, Süleyman Demirel Üniversitesi, Sağlık Bilimleri Fakültesi, Hemşirelik Bölümü, Cerrahi Hastalıkları Hemşireliği Anabilim Dalı, Isparta, Türkiye, E-mail: altun.baksi@hotmail.com, Tel: 0246 2113267, ORCID: 0000-0001-8267-2254.

${ }^{2}$ Dr. Öğr. Üyesi, Dokuz Eylül Üniversitesi, Hemşirelik Fakültesi, Cerrahi Hastalıkları Hemşireliği Anabilim Dalı, İzmir, Türkiye, E-mail: aylin_durmaz@yahoo.com, Tel: 0232 4124764, ORCID: 0000-0002-0681-5863.

Geliş Tarihi: 27 Kasım 2019, Kabul Tarihi: 05 Mayıs 2020

Atıf/Citation: Baksi A, Durmaz Edeer A. Yoğun Bakım Hemşirelerinin Duygusal Emek ve Genel Sağlık Durumları Arasındaki Iliş̧inin İncelenmesi. Hacettepe Üniversitesi Hemşirelik Fakültesi Dergisi 2020; 7(2): 130-137. DOI: 10.31125/hunhemsire.763157
} 


\section{GíRiş}

Geçmişte duygular işyeri olgusu içerisinde ihmal edilmiş ve açıklanmaya gerek duyulmamıştır ${ }^{1}$. Günümüzde hizmet sektörünün yükselişi ile normal şartlarda soyut ve kişiye özel nitelikte olan duygu, ekonomik değeri olan ve örgütün verimliliğini arttıracak somut bir ürün haline gelmiştir ${ }^{2,3}$. Bu anlayış neticesinde çalışma hayatında kişiden fiziksel ve zihinsel güç gibi duygularını da işin gerekliliklerine uyarlamaları beklenmektedir. Bu doğrultuda "duygu" ve "emek" kavramlarından yola çıkılarak duygusal emek "çalışanın işini yaparken duygularını düzenlemesi" olarak tanımlanmıştı ${ }^{4,5}$. Duygusal emek kişilerarası hizmet işlemleri sırasında örgütsel olarak gerekli duygular olarak tanımlanan örgütsel "kurallar" ile tutarlı olmak için duyguları ve duygusal ifadeleri yönetme eylemini ifade eder ${ }^{6}$.

Duygusal emek kavramı ilk defa 1983 yılında sosyolog Hochschild tarafından kavramsallaştırılmıştır. Duygusal emek kavramı, yüzeysel ve derinlemesine davranış olarak iki boyutta incelenmiştir7. Yüzeysel davranışta birey, yalnızca davranışlarını değiştirerek beklentilere uyumlu hale getirmekte gerçekte öyle hissetmediği halde hissediyormuş gibi davranmaktadır. Derinlemesine davranışta ise, birey duygularını düzenleyerek $o$ anda yansıtması gereken duyguyu gerçekten hissediyor hale gelmekte ve ona uygun davranış göstermektedir ${ }^{7-10}$. Ashforth ve Humphrey (1993), bu davranışlara "spontane ve samimi duygular" kavramını eklemiştir. Bu alt boyutta çalışanların öz duyguları ile beklenen arasında fark bulunmamakta ve duygularını yönetmeye gerek kalmadan doğal (samimi) duygularla davranmaktadır ${ }^{11}$. Literatürde duygusal emeğin olumlu ve olumsuz sonuçları olduğu belirtilmektedir ${ }^{8,10,12}$. Mann (2005) tarafından oluşturulan duygusal emek sağlık bakım modeline göre; duygusal emek sürecinin yönetilme durumuna göre olumlu sonuçları arasında duygusal uyum/denge, hastalarla kurulan iyi iletişim ve iş doyumu yer alırken, olumsuz sonuçları arasında duygusal çatışma, bozulmuş benlik saygısı, depresyon, yabancılaşma, aşırı rol yüklenmesi, memnuniyetsizlik, stres, tükenmişlik, iş doyumunun azalması ve fizyolojik problemler yer almaktadır ${ }^{8}$.

Özellikle insan unsurunun ön planda olduğu işlerde duyguların yoğunluğu daha da fazla hissedilmektedir ${ }^{10}$. Bunlar öncelikle hemşireler, doktorlar, öğretmenler, havayolu personeli, sosyal hizmet uzmanları, çağrı merkezi çalışanları ve satış görevlileri gibi mesleklerdir ${ }^{12}$. Duygusal emek kişilerarası ilişkiler hakkında bilgi vermesi ve bakım kalitesi açısından önemlidir ${ }^{13}$. Yoğun bakım birimleri stres yaratan birimlerdir ve hastalar ile yoğun ve sürekli iletişim halinde olan hemşireler için duygusal yük getirmektedir. Yoğun bakım birimlerinde yatan hastaların yoğun duygusal/ruhsal desteğe gereksinimi bulunmaktadır ${ }^{14}$. Hastalar hizmet sunumunda psikolojik sürece göre hizmetlerini değerlendirir ve duygusal gereksinimlerini karşılayan kişilerin iyi hizmet sunduğunu düşünür ${ }^{15}$. Bu anlayışla duyguların düzenlenmesinde bir takım durumsal, bireysel değişkenler ve örgütsel faktörler etkili olabilmektedir ${ }^{2}$. Yoğun bakım hemşirelerinin bu görev ve sorumlulukları yerine getirebilmeleri için de ruhsal olarak sağlıklı bir yapıya sahip olmaları gerekmektedir. Yoğun bakım hemşireleri üzerinde yapılan bir araştırmada ruhsal sağlık durumlarının hastalık düzeyinde olmadığı fakat sürekli ve belirli aralıklar ile değerlendirilmesi önerilmektedir ${ }^{16}$. Literatürde duygusal emek ile ilgili birçok çalışma yapıldığı görülmektedir. Literatürde duygusal emek takım iklimi algılanan bakım kalitesi ${ }^{17}$, cinsiyet $^{18}$ ve stres ${ }^{19,20}$ arasında ilişkiyi inceleyen bir çok araştırma bulunmaktadır. ülkemizde hemşirelerin duygusal emek süreçleri ile ilgili olarak yapılan araştırmalarda; tükenmişlik ${ }^{1,12,15}$, demografik faktörler arasındaki ilişki ${ }^{21}$, maneviyat ${ }^{22,23}$ ve yoğun bakım ve klinik hemşirelerinde duygusal emek ile empati eğilimi ${ }^{14}$ incelenmiştir. Fakat ülkemizde yoğun bakım hemşirelerinde duygusal emek ve genel sağlık durumları arasındaki ilişkinin incelendiği herhangi bir çalışmaya ulaşılamamıştır.

\section{Araştırmanın Amacı}

$\mathrm{Bu}$ araştırmanın amacı, yoğun bakım birimlerinde çalışan hemşirelerin duygusal emeğin yordayıcısı olarak genel sağlık, sosyo-demografik ve mesleğe ilişkin bazı özelliklerinin incelenmesidir.

\section{GEREÇ ve YÖNTEM}

\section{Araştırmanın Türü}

$\mathrm{Bu}$ çalışma tanımlayıcı, kesitsel ve ilişkisel tipte bir araştırmadır.

\section{Araştırmanın Evreni ve Örneklemi}

Araştırma, birisi Türkiye'nin batısında, diğeri güneydoğusunda yer alan iki üniversite hastanesinde çalışan yoğun bakım hemşirelerinde Temmuz-Aralık 2018 tarihleri arasında yürütülmüştür. Araştırmanın evrenini; Türkiye'nin güneydoğusunda (n:142) ve batısında (n:130) yer alan üniversite hastanelerinin yoğun bakım kliniklerinde görev yapan hemşireler oluşturmuştur (n:272). Örneklem büyüklüğünün hesaplanmasında Sample Size Calculator programı kullanılmıştır. Evren üzerinden yapılan örneklem büyüklüğünün hesaplanmasında evren 272 ve $p=0.05$ alındığında örneklem büyüklüğü 159 olarak hesaplanmıştır. Örneklem seçiminde tabakalı örnekleme yöntemi kullanılmıştır. İki üniversite hastanesi iki ayrı tabaka olarak ayrımıştır. Tabaka ağırlığı ve tabakadan alınacak hemşire sayısı belirlenmiştir. Güneydoğu bölgesindeki üniversite hastanesinden toplam 83 hemşire, batı bölgesindeki hastaneden toplam 76 hemşirenin rasgele örnekleme alınması belirlenmiştir. Araştırma örneklemini toplam 152 hemşire oluşturmuştur. Araştırma örneklemine alınma kriterleri; hemşirelerin araştırmaya katılmak için gönüllü olması, kuruma/birime uyum sürecini tamamlaması açısından 6 ay ve üzeri yoğun bakım ünitesinde çalışmış olmasıdır ${ }^{10,24}$.

\section{Veri Toplama Araçları}

Araştırma verileri; Tanıtıcı Bilgiler Formu, Hemşirelerin Duygusal Emek Davranışı Ölçeği ve Genel Sağlık Anketi (GSA12) kullanılarak toplanmıştır.

Tanıtıcı Özellikler Formu: Tanıtıcı bilgiler formu, hemşirelerin sosyo-demografik "yaş, cinsiyet, medeni ve eğitim durumu, ekonomik durum algısı, çocuk sayısı" ve 
klinik/mesleki özellikler ile ilgili "yoğun bakımda ve meslekte deneyim süresi, çalışılan yoğun bakım birimi, birimden memnuniyet durumu, kliniğin yoğunluk derecesi, haftalık çalışma saati, çalışma şekli, yoğun bakımda isteği ile çalışma durumu, mesleği sevme düzeyi, mesleği bırakma isteği, mesleği yeniden seçme, istihdam şekli, önceden psikolojik bir sorun yaşama ve destek alma durumu, çalışma saatlerinde ortalama sorumlu olunan hasta sayısı" sorulardan oluşmaktadır10,14,24.

Hemşirelerin Duygusal Emek Davranışı Ölçeği: Ölçek, hemşirelerin duygusal emek davranışının belirlenmesi amacıyla Değirmenci tarafından 2016 yılında geliştirilmiştir. Ölçek, 24 madde ve üç alt boyuttan "yüzeysel davranış, derinlemesine davranış ve samimi davranış" oluşmaktadır. Ölçek, 5'li likert tipinde puanlanmakta ve olumsuz ters puanlanan madde bulunmamaktadır. Ölçeğin cronbach alfa iç tutarlılık güvenilirlik katsayı değerlerinin derinlemesine davranışta .86, yüzeysel ve samimi davranış alt boyutunda .75 ve tüm ölçek için .90 olduğu saptanmıştır. Ölçek alt boyut puan ortalamalarının yükselmesi, o davranışın gösterildiği şeklinde değerlendirilmektedir. Ölçekten alınan puanlar değerlendirilirken; her bir alt boyuttan alınan toplam puan, alt boyuttaki madde sayısına bölünerek aritmetik ortalaması alınmaktadır. Buna göre her bir alt boyutta alt boyut puan ortalaması " 1 " ve " 5 " arasında değişmektedir. Ölçek alt boyutlarda ortalama puan "1"e yaklaştıkça duygusal emek davranışının düşük olduğu, puan "5"e yaklaştıkça davranışın yüksek olduğu şeklinde değerlendirilmektedirio,24.

Genel Sağlık Anketi (GSA-12): GSA, Goldberg tarafından toplumda sık rastlanan akut ruhsal rahatsızlıkları yakalamak amacıyla geliştirilmiştir. Ölçek genel psikopatoloji düzeyini saptamakta ve toplum taramalarında psikiyatrik vaka bulmakta kullanılmaktadır. Ölçeğin 12, 28, 30 ve 60 soruluk formları bulunmaktadır. Bu çalışmada hemşirelerin genel ruhsal sağlık durumunu belirlemek amacıyla 12 soruluk formu kullanılmıştır. Her soru 4 seçenekten oluşmaktadır. Yanıtlar likert (0-1-2-3) ölçeği şeklinde veya GSA el kitabında önerildiği şekilde (0-0-1-1) puanlanabilir. Puanlamada GHQ (General Health Questionnaire-GHQ) tipi puanlama adı verilen yöntem kullanılmıştır ${ }^{25}$. Buna göre ilk iki kolon 0 , son iki kolon da 1 olarak puanlanmaktadır. Bu tip puanlamanın kullanıldığı araştırmaların çoğunda GSA12 için en uygun kesme noktasının 1 ve 2 puan arası olduğu belirtilmiştir. İki ve üstü puan alanlar riskli grup olarak değerlendirilmektedir. Güvenilirlik çalışmasında Cronbach alfa iç tutarlııı katsayısı 0.78 bulunmuştur. Genel sağlık durumu puanının yüksek olması kişilerin ruhsal sağıı durumlarının riskli olduğunu ve ruhsal problemler yaşadığını göstermektedir ${ }^{26}$.

\section{Verilerin Toplanmas}

Araştırma verileri; birisi Türkiye'nin batısında ve diğeri güneydoğusunda yer alan iki üniversite hastanesinde Temmuz-Aralık 2018 tarihleri arasında toplanmıştır. Araştırma verileri toplanmadan önce araştırmacılar tarafından her iki üniversite hastanesinde yer alan her bir yoğun bakım hemşiresi ile yüz-yüze görüşülerek araştırma ile ilgili bilgi verilmiştir. Daha sonra formlar araştırmaya katılmayı kabul eden hemşireler tarafından ortalama 4-5 dakikada doldurulmuştur. Veri toplama sürecinde hemşirelerin uygun olduğu zamana ve verilerin uygun bir ortamda doldurulmasına dikkat edilmiştir.

\section{Verilerin Değerlendirilmesi}

Araştırma verileri bilgisayar ortamında SPSS 24.00 (Statistical Package for the Social Sciences) istatistik paket programı kullanılarak analiz edilmiştir. Hemşirelerin tanıtıcı bilgileri için tanımlayıcı istatistiklerden sayı, yüzde, ortalama ve standart sapma kullanılmıştır. Duygusal emek alt boyutları ile ilişkili olan değişkenler korelasyon analizi ile belirlenmiştir. Korelasyon analizinde bağımlı değişken olan duygusal emek ile ilişkisi istatistiksel olarak anlamlı çıkan bağımsız değişkenler stepwise çoklu doğrusal regresyon analizine alınmış ve duygusal emeği açıklama yüzdesi belirlenmiştir. Regresyon modeli oluşturulurken modelin standartlaştırımış artıkları ve değişkenler arası çoklu bağlantı problemi incelenmiştir ${ }^{27}$. Regresyon analizinde cinsiyet, mesleği sevme, mesleği bırakma isteği, ekonomik durum algısı ve klinik yoğunluk derecesi değişkenleri kategorik değişkenler olduğu için kukla (dummy) değişken olarak analize dahil edilmiştir. Değişkenlerin regresyon eşitliğine alınabilmesi için istatistiksel anlamlılık düzeyi $\alpha<0.05$ kabul edilmiştir.

\section{Araştırmanın Etik Boyutu}

Araştırma için Türkiye'nin güneydoğusunda bir üniversite hastanesi Tıp Fakültesi'nin etik kurulundan onay alınmıştır (Karar No: 195, Karar tarihi: 06.06.2018). Araştırmanın yürütüleceği hastanelerden ve kullanılan ölçüm araçları için uyarlamasını yapan yazarlardan yazılı izin alınmıştır. Yine hemşirelerden "Bilgilendirilmiş Onam Formu" kullanılarak sözel izin alınmıştır.

\section{BULGULAR}

Araştırmaya katılan yoğun bakım hemşirelerinin yaş ortalaması $30.28( \pm 5.35)$ (en az-en fazla=19.00-47.00), \%68.4'ü kadın ve \%53.3'ü evlidir. Hemşirelerin \%68.5'i lisans mezunu, \%77'si ekonomik durumunu orta düzey olarak algılamakta ve çocuk sayısı ortalaması $1.6 \pm .86$ (en az-en fazla=0-4)' dır. Yoğun bakım hemşirelerinin \%42.2'sinin 6-10 yıl arasında yoğun bakım deneyimi bulunmakta, \%29.6'sı dahili ve \%11.2'si cerrahi birim yoğun bakımda çalışmakta, \%49.4'ü çalıştığı birimden memnun, \%73'ü çalıştığı kliniğin yoğunluğunu "çok" olarak ifade etmekte, \%44.7'si haftalık çalışma saatinin 41-50 saat olduğu ve \%84.2'si gece-gündüz dönüşümlü olarak çalıştığını belirtmiştir. Hemşirelerin \%80.3'ü yoğun bakımda isteği ile çalıştığını, \%53.3'ü mesleğini "orta düzeyde" sevdiğini, \%77'si imkanı olsa mesleği bırakmak istediğini ve \%42.1'i mesleği yeniden seçme şansı olursa yine seçebileceğini belirtmiştir. Hemşirelerin \%55.3'ü kadrolu ve sorumlu olunan/bakım verilen hasta sayısı ortalaması $5.05( \pm 2.95)$ dir. Hemşirelerin genel sağlık ölçeğine göre \%65.1'i riskli gruptadır (Tablo 1). Yoğun bakım hemşirelerinin duygusal emek ölçeğinin derinlemesine davranış alt boyut puanı $3.72( \pm 0.68)$, samimi davranış alt boyut puanı $3.83( \pm 0.76)$ ve yüzeysel davranış alt boyut puanı $3.67( \pm 0.77)$, genel sağılı ölçeği puan ortalaması ise $3.55( \pm 3.20)$ olarak saptanmıştır (Tablo 1 ). 
Tablo 1. Yoğun Bakım Hemşirelerinin Mesleki Özellikleri, Duygusal Emek ve Genel Sağlık Ölçek Puanları (n=152)

\begin{tabular}{|c|c|c|}
\hline Değişkenler & Sayı & Yüzde \\
\hline \multicolumn{3}{|l|}{ Yoğun bakım deneyim süresi } \\
\hline 6 ay-1 yıl & 11 & 7.2 \\
\hline $1-5 \mathrm{yll}$ & 49 & 32.2 \\
\hline $6-10$ yıl & 64 & 42.2 \\
\hline 11 yıl ve üstü & 28 & 18.4 \\
\hline \multicolumn{3}{|l|}{ Meslekte deneyim süresi } \\
\hline 6 ay-1 yıl & 6 & 3.9 \\
\hline $1-5 \mathrm{yıl}$ & 40 & 26.3 \\
\hline $6-10 \mathrm{yıl}$ & 66 & 43.5 \\
\hline 11 yıl ve üstü & 40 & 26.3 \\
\hline \multicolumn{3}{|l|}{ Çalışılan yoğun bakım birimi } \\
\hline Cerrahi & 17 & 11.2 \\
\hline Dahili & 45 & 29.6 \\
\hline Anestezi & 7 & 4.6 \\
\hline Yenidoğan & 31 & 20.4 \\
\hline Acil & 7 & 4.6 \\
\hline Onkoloji & 8 & 5.3 \\
\hline Yanık & 3 & 2.0 \\
\hline Çocuk & 10 & 6.9 \\
\hline Koroner & 15 & 9.9 \\
\hline Göğüs kalp damar cerrahisi & 9 & 5.9 \\
\hline \multicolumn{3}{|c|}{ Çalışılan birimden memnuniyet durumu } \\
\hline Evet & 75 & 49.4 \\
\hline Kısmen & 44 & 28.9 \\
\hline Hayır & 33 & 21.7 \\
\hline \multicolumn{3}{|l|}{ Klinik yoğunluk derecesi } \\
\hline Orta & 41 & 27.0 \\
\hline Çok & 111 & 73.0 \\
\hline \multicolumn{3}{|l|}{ Haftalık çalışma saati } \\
\hline 40 & 22 & 14.5 \\
\hline $41-50$ & 68 & 44.7 \\
\hline $51-60$ & 36 & 23.7 \\
\hline $61 \geq$ & 26 & 17.1 \\
\hline \multicolumn{3}{|l|}{ Çalışma şekli } \\
\hline Sürekli gündüz & 17 & 11.2 \\
\hline Sürekli gece & 7 & 4.6 \\
\hline Gece-gündüz dönüşümlü & 128 & 84.2 \\
\hline \multicolumn{3}{|c|}{ Yoğun bakımda isteği ile çalışma durumu } \\
\hline Evet & 122 & 80.3 \\
\hline Hayır & 30 & 19.7 \\
\hline \multicolumn{3}{|l|}{ Mesleği sevme durumu } \\
\hline Hiç sevmiyorum & 12 & 7.9 \\
\hline Az seviyorum & 35 & 23.0 \\
\hline Orta düzeyde seviyorum & 81 & 53.3 \\
\hline Çok seviyorum & 24 & 15.8 \\
\hline \multicolumn{3}{|c|}{ Mesleği bırakma isteği (imkanı olması durumunda) } \\
\hline Evet & 117 & 77.0 \\
\hline Hayır & 35 & 23.0 \\
\hline \multicolumn{3}{|l|}{ Mesleği yeniden seçme } \\
\hline Evet & 64 & 42.1 \\
\hline Hayır & 88 & 57.9 \\
\hline \multicolumn{3}{|l|}{ îstihdam şekli } \\
\hline Kadrolu & 84 & 55.3 \\
\hline Sözleşmeli & 68 & 44.7 \\
\hline
\end{tabular}

Tablo 1. Yoğun Bakım Hemşirelerinin Mesleki Özellikleri, Duygusal Emek ve Genel Sağlık Ölçek Puanları (n=152) (devamı)

\begin{tabular}{|l|l|l|}
\hline Değişkenler & Sayı & Yüzde \\
\hline $\begin{array}{l}\text { Daha önce psikolojik bir sorun } \\
\text { yaşama durumu }\end{array}$ & 2 & 1.3 \\
\hline Evet & 150 & 98.7 \\
\hline Hayır & \multicolumn{2}{|l|}{} \\
\hline $\begin{array}{l}\text { Daha önce psikolojik destek } \\
\text { alma durumu }\end{array}$ \\
\hline Evet & 11 & 7.2 \\
\hline Hayır & 141 & 92.8 \\
\hline Genel sağlık ölçeği & 53 & 34.9 \\
\hline Normal & 99 & 65.1 \\
\hline Riskli grup & $\mathbf{X} \pm$ SS & Min-Maks \\
\hline Sorumlu olunan hasta sayısı & $5.05 \pm 2.95$ & $2.00-23.0$ \\
\hline Duygusal emek alt boyutları & $3.72 \pm .68$ & $1.00-5.00$ \\
\hline Derinlemesine davranış & $3.83 \pm .76$ & $1.00-5.00$ \\
\hline Samimi davranış & $3.67 \pm .77$ & $1.00-5.00$ \\
\hline Yüzeysel davranış & $3.55 \pm 3.20$ & $0.00-11.00$ \\
\hline Genel sağlık puan ortalaması
\end{tabular}

\section{Korelasyonlar}

Araştırmada regresyon modelindeki bağımsız değişkenler arasındaki korelasyon değerleri Tablo 2'de gösterilmiştir. Korelasyon analizi sonucunda; yoğun bakım hemşirelerinin yüzeysel davranış ve samimi davranış ile genel sağlık durumu arasında ilişki olmadığı, derinlemesine davranış ile negatif yönde anlamlı zayıf ilişki olduğu ( $r:-0.171, p: 0.035$; $p<0.05$ ) bulunmuştur (Tablo 2). Bu ilişki, hemşirelerin genel sağlık durumu puanı arttıkça hastalara derinlemesine davranışların azaldığını göstermektedir.

Duygusal emek derinlemesine davranış alt boyutu ile mesleği sevme $(r=0.274 ; p:<0.001)$ ve mesleği bırakma isteği $(r=0.198)$ arasında pozitif yönde, cinsiyet $(r=-0.166$; $p:<0.041)$ ile negatif yönde istatistiksel olarak anlamlı bir ilişki belirlenmiştir $(p<0.05)$ (Tablo 2).

Duygusal emek samimi davranış alt boyutu ile mesleği sevme ( $r=0.282 ; p: 0.000)$ ve mesleği bırakma isteği $(r=0.173)$ arasında pozitif yönde, sorumlu olunan hasta sayısı ( $r=-0.162$ ) ile negatif yönde istatistiksel olarak anlamlı bir ilişki belirlenmiştir $(p<0.01)$ (Tablo 2).

Duygusal emek yüzeysel davranış alt boyutu ile ekonomik durum algısı ( $r=0.207)$, mesleği sevme ( $r=0.377 ; p: 0.000)$ ve klinik yoğunluk ( $r=0.214$; $p: 0.008$ ) arasında istatistiksel olarak pozitif yönde anlamlı bir ilişki belirlenmiştir $(p<0.05)$ (Tablo 2).

Duygusal Emek Ölçeğinin Derinlemesine, Yüzeysel ve Samimi Davranış Alt Boyutlarının Modellenmesi

Yoğun bakım hemşirelerinin derinlemesine, samimi ve yüzeysel davranış ile korelasyonda anlamlı ilişki saptanan tanıtıcı özellikler ayrı modeller kurularak regresyon modeline alınmıştır (Tablo 3,4,5). Üç ayrı regresyon modelininde anlamlı olduğu saptanmıştır. Hemşirelerde derinlemesine davranış alt boyutu incelendiğinde, mesleği sevme durumunun (Evet) $(\beta=0.185, p<0.05)$ derinlemesine davranış alt boyutu için istatistiksel olarak anlamlı ve pozitif yönlü bir yordayıcı olduğu ve toplam varyansın \%9'nu açıkladığı görülmektedir (Tablo 3). 
Tablo 2. Duygusal Emek ve Bağımsız Değişkenler ( $n=152)$

\begin{tabular}{|c|c|c|c|c|}
\hline Değişkenler & 1 & 2 & 3 & 4 \\
\hline $\begin{array}{l}\text { 1. Derinlemesine } \\
\text { davranış }\end{array}$ & - & & & \\
\hline 2. Samimi davranış & $\begin{array}{l}0.864^{*} \\
*\end{array}$ & - & & \\
\hline $\begin{array}{l}\text { 3. Yüzeysel } \\
\text { davranış }\end{array}$ & $\begin{array}{l}0.776 * \\
*\end{array}$ & $0.723 * *$ & - & \\
\hline $\begin{array}{l}\text { 4. Genel Sağlık } \\
\text { Durumu }\end{array}$ & $-0.171^{*}$ & 0.148 & -0.136 & - \\
\hline 5. Yaş & 0.034 & -0.026 & 0.070 & 0.031 \\
\hline 6. Cinsiyet (Erkek) & $-0.166^{*}$ & -0.073 & 0.058 & 0.154 \\
\hline 7. Medeni durum & -0.082 & -0.089 & -0.002 & 0.008 \\
\hline 8. Eğitim durumu & -0.038 & 0.074 & 0.062 & 0.101 \\
\hline $\begin{array}{l}\text { 9. Ekonomik durum } \\
\text { algISI }\end{array}$ & 0.155 & 0.126 & $0.207^{*}$ & $-0.227^{* *}$ \\
\hline $\begin{array}{l}\text { 10. Mesleki } \\
\text { deneyim }\end{array}$ & 0.000 & -0.100 & 0.008 & 0.001 \\
\hline $\begin{array}{l}\text { 11.Yoğun bakım } \\
\text { deneyimi }\end{array}$ & -0.074 & -0.156 & -0.123 & 0.004 \\
\hline $\begin{array}{l}\text { 12. Birimden } \\
\text { memnuniyet } \\
\text { durumu }\end{array}$ & -0.136 & 0.132 & 0.049 & $0.233^{* *}$ \\
\hline $\begin{array}{l}\text { 13. Klinik yoğunluk } \\
\text { derecesi }\end{array}$ & 0.056 & 0.011 & $\begin{array}{l}0.214^{*} \\
*\end{array}$ & -0.003 \\
\hline $\begin{array}{l}\text { 14. Haftalık çalışma } \\
\text { saati }\end{array}$ & -0.099 & -0.001 & -0.071 & $0.202^{*}$ \\
\hline $\begin{array}{l}\text { 15. Yoğun bakımda } \\
\text { çalışmayı isteme } \\
\text { durumu }\end{array}$ & 0.022 & 0.047 & 0.028 & 0.084 \\
\hline $\begin{array}{l}\text { 16. Mesleği sevme } \\
\text { durumu (Evet) }\end{array}$ & $\begin{array}{l}0.274^{*} \\
*\end{array}$ & $0.282^{*}$ & $\begin{array}{l}0.377^{*} \\
*\end{array}$ & $-0.350 * *$ \\
\hline $\begin{array}{l}\text { 17. Sorumlu olunan } \\
\text { hasta sayısı }\end{array}$ & -0.154 & $-0.162^{*}$ & -0.157 & 0.110 \\
\hline $\begin{array}{l}\text { 18. Mesleği } \\
\text { bırakma isteği } \\
\text { (Hayır) }\end{array}$ & $0.198 *$ & 0.173* & 0.139 & $-0.206^{*}$ \\
\hline
\end{tabular}

Tablo 3. Derinlemesine Davranış Alt Boyutunun Modellenmesi $(n=152)$

\begin{tabular}{|c|c|c|c|c|c|}
\hline & Beta & SH & $\beta$ & $t$ & $\mathbf{p}$ \\
\hline \multicolumn{6}{|l|}{$\begin{array}{l}\text { Derinlemesine } \\
\text { davranış }\end{array}$} \\
\hline Constant & 3.321 & 0.315 & & 10.548 & 0.000 \\
\hline $\begin{array}{l}\text { Genel sağlık } \\
\text { toplam puanı }\end{array}$ & -0.014 & 0.018 & -0.067 & -0.782 & 0.435 \\
\hline Cinsiyet & -0.140 & 0.117 & -0.095 & -1.190 & 0.236 \\
\hline $\begin{array}{l}\text { Mesleği sevme } \\
\text { durumu (Evet) }\end{array}$ & -0.157 & 0.077 & 0.185 & 2.046 & $0.043^{*}$ \\
\hline $\begin{array}{l}\text { Mesleği } \\
\text { bırakma isteği }\end{array}$ & 0.163 & 0.137 & 0.102 & 1.190 & 0.236 \\
\hline $\mathrm{R}$ & \multicolumn{5}{|l|}{0.308} \\
\hline $\mathrm{R}^{2}$ & \multicolumn{5}{|l|}{0.095} \\
\hline $\mathrm{F}$ & \multicolumn{5}{|l|}{3.862} \\
\hline$p$ & \multicolumn{5}{|l|}{0.005} \\
\hline DW (1.5-2.5) & \multicolumn{5}{|l|}{1.980} \\
\hline
\end{tabular}

*Cinsiyet (0: kadın, 1: erkek), mesleği sevme durumu (0: evet, 1: hayır) mesleği bırakma isteği (0:hayır, 1 : evet) değişkenleri kategorik değişkenlerdir.
Hemşirelerde samimi davranış alt boyutu incelendiğinde, bu modelin anlamlı olduğu fakat hiçbir değişkenin samimi davranış alt boyutu için istatistiksel olarak anlamlı bir yordayıcı olmadığı bulunmuştur ve bu değişkenlerin toplam varyansın \%0.8'ni açıkladığı görülmektedir (Tablo 4).

Tablo 4. Samimi Davranış Alt Boyutunun Modellenmesi $(n=152)$

\begin{tabular}{|l|l|l|l|l|l|}
\hline & Beta & SH & $\boldsymbol{\beta}$ & $\mathbf{t}$ & $\mathbf{p}$ \\
\hline $\begin{array}{l}\text { Samimi } \\
\text { davranış }\end{array}$ & & & & & \\
\hline Constant & 3.337 & 0.265 & & 12.617 & 0.000 \\
\hline $\begin{array}{l}\text { Mesleği } \\
\text { sevme } \\
\text { durumu }\end{array}$ & 0.150 & 0.081 & 0.158 & 1.844 & 0.067 \\
\hline $\begin{array}{l}\text { Sorumlu } \\
\text { olunan hasta } \\
\text { sayısı }\end{array}$ & -0.039 & 0.020 & -0.151 & 1.907 & 0.058 \\
\hline $\begin{array}{l}\text { Mesleği } \\
\text { bırakma isteği }\end{array}$ & 0.224 & 0.154 & 0.125 & 1.455 & 0.148 \\
\hline $\mathrm{R}$ & 0.286 & & & & \\
\hline $\mathrm{R}^{2}$ & 0.082 & & & & \\
\hline $\mathrm{F}$ & 4.405 & 0.005 & & \\
\hline $\mathrm{P}$ & 1.889 & & \\
\hline DW (1.5-2.5) & & & & \\
\hline
\end{tabular}

*Mesleği sevme durumu (0: evet, 1: hayır), mesleği bırakma isteği (0:hayır, 1: evet) değişkenleri kategorik değişkenlerdir.

Hemşirelerde yüzeysel davranış alt boyutu incelendiğinde, modelin anlamlı olduğu, mesleği sevme durumu $(\beta=0.298$, $p<0.001)$ ve ekonomik durum algISI $(\beta=0.211, p<0.05)$ yüzeysel davranış alt boyutu için istatistiksel olarak anlamlı ve pozitif yönlü yordayıcılar olduğu ve toplam varyansın \%16'sını açıkladığı görülmektedir (Tablo 5).

Tablo 5. Yüzeysel Davranış Alt Boyutunun Modellenmesi $(n=152)$

\begin{tabular}{|c|c|c|c|c|c|}
\hline & B & SH & B & t & $n$ \\
\hline \multicolumn{6}{|l|}{$\begin{array}{l}\text { Yüzeysel } \\
\text { davranış }\end{array}$} \\
\hline Constant & 1.908 & 0.433 & & 4.408 & 0.000 \\
\hline $\begin{array}{l}\text { Ekonomik } \\
\text { durum algısı }\end{array}$ & 0.327 & 0.118 & 0.211 & 2.779 & $0.006 *$ \\
\hline $\begin{array}{l}\text { Mesleği sevme } \\
\text { durumu (Evet) }\end{array}$ & 0.285 & 0.073 & 0.298 & 3.985 & $0.000 *$ \\
\hline $\begin{array}{l}\text { Klinik yoğunluk } \\
\text { derecesi }\end{array}$ & 0.112 & 0.127 & 0.067 & 0.885 & 0.378 \\
\hline $\mathrm{R}$ & \multicolumn{5}{|l|}{0.403} \\
\hline $\mathrm{R}^{2}$ & \multicolumn{5}{|l|}{0.163} \\
\hline $\mathrm{F}$ & \multicolumn{5}{|l|}{9.586} \\
\hline$p$ & \multicolumn{5}{|l|}{0.000} \\
\hline DW (1.5-2.5) & \multicolumn{5}{|l|}{1.886} \\
\hline
\end{tabular}

*Mesleği sevme durumu (0: evet, 1: hayır), ekonomik durum algısı (0: orta, 1:iyi), klinik yoğunluk derecesi (0:orta, 1:çok) değişkenleri kategorik değişkenlerdir. 


\section{TARTIŞMA}

Bu çalışmanın amacı; yoğun bakım hemşirelerinin duygusal emeğin yordayıcısı olarak genel sağlık, sosyo-demografik ve mesleğe ilişkin bazı özelliklerinin incelenmesidir. Araştırma bulgularına bakıldığında hemşirelerde duygusal emeğin derinlemesine davranış alt boyutunda mesleği sevmenin ve yüzeysel davranış alt boyutunda mesleği sevme ve ekonomik durum algısının anlamlı yordayıcı olduğu saptanmıştır. Yoğun bakım hemşirelerinin mesleği sevme düzeyi arttıkça "derinlemesine ve yüzeysel davranışın" arttığı saptanmıştır. Hemşirelik öğrencileri üzerinde yapılan bir araştırmada psikolojik açıdan rahatlamak için işini yaparak motivasyon geliştirenlerin derinlemesine davranışlarının arttığı saptanmıştır ${ }^{22}$. Hemşirelerin mesleğe yönelik tutumları ile mesleki profesyonelliklerinin incelendiği bir araştırmada mesleğini seven hemşirelerin profesyonel tutum ve mesleğe yönelik olumlu tutum puan ortalamalarının daha yüksek olduğu saptanmıştır ${ }^{28}$. Yine cerrahi kliniklerde çalışan hemşirelerde mesleğini seven hemşirelerin profesyonel tutumlarının daha yüksek olduğu saptanmıştır ${ }^{29,30}$. Literatürde profesyonelliğin en önemli ölçütü olarak işin gereklerini en mükemmel şekilde yerine getirmek olduğu ve profesyonel hemşirelerin niteliklerinden birisinin sorumluluk olduğu belirtilmektedir ${ }^{31}$. Bu doğrultuda mesleğini seven hemşirelerin profesyonel tutumları ile kendilerinden beklenen rol ve sorumlulukları derinlemesine ve yüzeysel davranış göstererek yerine getirdiği düşünülmektedir. Yine yapılan bir araştırmada mesleğini severek yapan hemşirelerin iş doyumunun daha yüksek olduğu belirlenmiştir. Literatürde iş doyumunun çalışanın başarılı, üretken ve mutlu olabilmesi için önemli bir durum olduğu belirtilmektedir ${ }^{32}$. Dahili yoğun bakım birimlerinde çalışan hemşireler üzerinde yapılan bir çalışmada işlerini sevmeyen hemşirelerin örgütsel rahatsızlıklarının daha çok olduğu saptanmıştır ${ }^{33}$. Yine literatürde duygularını iyi yönetenlerin daha iyi refah ve daha düşük iş stresi gösterdikleri belirtilmiştir6,19. Bu doğrultuda yine mesleğini seven hemşirelerin iş doyumunun daha yüksek olduğu ve örgütle daha uyumlu olduğu düşünülerek kendilerinden beklenen davranışı derinlemesine ve yüzeysel davranış şeklinde yerine getirdiği düşünülmektedir.

Yoğun bakım hemşirelerinin ekonomi durum algısı iyileştikçe "yüzeysel davranışın" arttığı saptanmıştır. Duygusal emek tanımları incelendiğinde ortak noktanın duyguların düzenlenmesi ve bunun bir ücret karşılığında yapılması olduğu görülmektedir. Yani çalışan işini başarıyla yerine getirebilmek amacıyla duygularını araçsallaştırmaktadır ${ }^{34}$. Hasta ilişkilerinde tıbbi sekreterlerin duygusal emek durumlarının incelendiği bir araştırmada kurumun belirlediği kuralları uygulamayanlar için hasta haklarından şikayet gelirse uyarı olduğu ve işten çıkarılma olabildiği belirtilmiştir ${ }^{35}$. Bu durum ekonomik kaygıları daha az olan hemşirelerin kendilerinden beklenen davranışı yerine getirdikleri fakat davranışın gerektirdiklerini hissetmek için çok fazla çaba harcamadıklarını düşündürmektedir.
Araştırma sonuçlarına bakıldığında genel sağlık durumunun derinlemesine, yüzeysel ve samimi davranış için anlamlı yordayıcı olmadığı saptanmıştır. Fakat derinlemesine davranış ve genel sağlık arasında negatif yönde anlamlı zayıf ilişki olduğu saptanmıştır. Genel sağlık durumu puanının yüksek olması kişilerin ruhsal sağlık durumlarının riskli olduğunu ve ruhsal problemler yaşadığını göstermektedir. Bu ilişki ruhsal problemler arttıkça derinlemesine davranışın azaldığını göstermektedir. Literatürde hemşirelerin iç kaynaklarını geliştirmek, duygusal emek için riskleri ve duygusal uyumsuzlukları önlemek için psikolojik dayanıklılığın önemli olduğu belirtilmiştir ${ }^{36}$. Farklı bir örneklem grubu olarak kamu sektöründe çalışanlar ile yapılan bir araştırmada derinlemesine davranış ve psikolojik/ruhsal sıkıntı arasında pozitif yönde bir ilişki olduğu saptanmıştır ${ }^{37}$. Araştırma örnekleminden farklı olarak hizmet sektöründe çalışanlar ile yapılan bir araştırmada yüzeysel davranışın daha kötü mental sağlık, derinlemesine ve samimi davranışın daha iyi mental sağlık ile ilişkili olduğu belirtilmiştir ${ }^{38}$. Hemşireler ve hemşirelik öğrencileri üzerinde yapılan bir araştırmada maneviyat arttıkça derinlemesine davranışın arttığı saptanmıştır22,23. Literatürde sürekli acil durum beklentisi, yüksek teknoloji karmaşıklığı, hastaların genel sağılk durumundaki ani değişim takipleri nedeniyle yoğun bakım kliniklerinin çalışanların ruhsal durumları açısından riskli ortamlar olduğu belirtilmektedir ${ }^{39}$. Yine yoğun bakım birimlerinde yatan hastaların yoğun ruhsal sorunları bulunmaktadır ${ }^{14}$. Hemşirelerden sadece kendi duygusal tepkilerini değil, hasta ve yakınlarının da korku ve stresini azaltması beklenmektedir ${ }^{40}$. Yapılan bir literatür incelemesinde yoğun bakım birimlerinde çalışan hemşirelerde stresli ortamın duygusal yük getirdiği ve \%70'lere varan oranda tükenmişlik yaşadıkları belirtilmektedir ${ }^{41}$. Bu doğrultuda hemşirelerin çalışma şartları ve tükenmişliğinde etkisiyle ruhsal problemleri arttıkça kendilerinden beklenen derinlemesine davranışı göstermek için çaba harcayamadıkları düşünülmektedir. Araştırmada genel sağlık durumunun yüzeysel ve samimi davranış için anlamlı yordayıcı olmaması bu davranışların herhangi bir çaba harcamadan gerçekleştirilmiş olması ile ilgili olabilir. Bu doğrultuda araştırmanın farklı örneklem gruplarında yapılması değişkenler ile aradaki ilişkinin belirlenmesi açısından önemlidir.

\section{SONUÇ ve ÖNERILER}

Bu çalışma; yoğun bakım hemşirelerinin duygusal emek ve genel sağlık düzeyi arasındaki ilişki hakkında bilimsel bilgi vermesi açısından literatüre katkı sağlamaktadır. Kurum yöneticileri hemşirelerin duygusal emek sürecini daha iyi yönetebilmesi için destek vermeli ve uygun klinik ortam oluşturulmalıdır. Yüksek motivasyon gerektiren yoğun bakım birimlerinde çalışan hemşirelerin mesleklerini sevmesi için gerekli stratejilerin geliştirilmesi önerilmektedir. Bu doğrultuda hemşirelerin mesleki memnuniyeti ve motivasyonlarını etkileyen durumların belirlenmesi, destekleyici iş ortamlarının oluşturulması, klinik yoğunluklarının ve sorumlu oldukları hasta sayısının 
azaltılmasının etkili olabileceği düşünülmektedir. Duygusal emek ve genel sağlık arasındaki ilişkinin belirlenmesine yönelik daha fazla çalışma yapılması önerilmektedir. Yine konu ile ilgili daha büyük örneklemlerle araştırma yapılması önerilmektedir.

Etik Kurul Onayı: Dicle Üniversitesi Tıp Fakültesi Girişimsel Olmayan Klinik Araştırmalar Etik Kurulu'ndan onay alınmıştır (Karar No: 195, Karar tarihi: 06.06.2018).

Çıkar Çatışması: Bildirilmemiştir.

Finansal Destek: Yoktur.

Katılımcı Onamı: Hemşirelerden bilgilendirilmiş onam

alınmıştır.

Yazar katkıları:

Araştırma dizaynı: $A B, A D E$

Veri toplama: $A B, A D E$

Veri analizi: $A D E$

Makale yazımı: AB, ADE

Teşekkür

Çalışmaya katılan tüm hemşirelere teşekkür ederiz.

Ethics Committee Approval: Approval was obtained from Non-interventional Clinical Research Ethics Committee of Dicle University (Decision number: 195, Decision date: 06.06.2018).

Confict of Interest: Not reported.

Funding: None.

Exhibitor Consent: Informed consent was obtained from nurses.

Author contributions:

Study design: $A B, A D E$

Data collection: $A B, A D E$

Data analyses: $A D E$

Drafting manuscript: $A B, A D E$

Acknowledgement: We would like to thank all nurses who participated to the study.

\section{KAYNAKLAR}

1. Yıldırım MH, Erul EE. Effects of emotional labor on employees burnout behavior. Organizasyon ve Yönetim Bilimleri Dergisi. 2013;5(1):89-99.

2. Basım HN, Beğenirbaş $M$. Çalışma yaşamında duygusal emek: Bir ölçek uyarlama çalışması. Yönetim ve Ekonomi: Celal Bayar Üniversitesi İktisadi ve İdari Bilimler Fakültesi Dergisi. 2012;19(1):77-90.

3. Pala T, Sürgevil O. Duygusal emek ölçeği: Ölçek geliştirme, güvenilirlik ve geçerlilik çalışması. Ege Academic Review. 2016;16(4):773-87.

4. Başbuğ G. Duygusal emeğin iş memnuniyetine etkisi: Çağrı merkezi çalışanlarına yönelik bir çalışma. Sosyal Siyaset Konferansları Dergisi. 2010;58: 253-74.

5. Kaya U, Ozhan ÇK. Emotional labor and burnout relationship: a research on tourist guides. Journal of Labour Relations. 2012;3(2):109-30.

6. Mikolajczak M, Menil C, Luminet O. Explaining the protective effect of trait emotional intelligence regarding occupational stress: Exploration of emotional labour processes. J Res Pers. 2007;41(5):1107-17.

7. Hochschild AR. The managed heart: Commercialization of human feeling. London, England: University of California Press, Ltd.; 1983.

8. Mann S. A health-care model of emotional labour. J Health Organ Manag. 2005;19(5):304-17. doi: 10.1108/14777260510615369

9. Grandey AA. Emotion regulation in the workplace: $A$ new way to conceptualize emotional labor. J Occup Health Psychol. 2000;5(1):95-110. doi: 10.1037//10768998.5.1.95

10. Degirmenci Oz S, Baykal U. Emotional labor behavior of nurses. J Health Nurs Manag. 2017;3(4):143-47. doi: 10.26650/FNJN.387142

11. Ashforth BE, Humphrey RH. Emotional labor in service roles: The influence of identity. Academy of Management Review. 1993;18(1):88-115.

12. Bayram N, Aytac S, Dursun S. Emotional labor and burnout at work: a study from Turkey. Procedia Soc Behav Sci. 2012;65:300-305. doi: 10.1016/j.sbspro.2012.11.126

13. Gray B. The emotional labour of nursing- defining and managing emotions in nursing work. Nurse Educ Today. 2009;29(2):168-75. doi:10.1016/j.nedt.2008.08.003

14. Tunc $P$, Gitmez $A$, Krespi Boothby MR. An investigation of emotional labor strategies on the basis of empathy among nurses working at intensive care and inpatient units. Anadolu Psikiyatri Derg. 2014;15(1):45-54. doi: 10.5455/apd.45762

15. Altuntas $S$, Altun ÖS. The relationship between emotional labor behaviors and burnout levels of nurses. J Health Nurs Manag. 2015;1(2):37-43. doi: 10.5222/SHYD.2015.037

16. Özgür G, Yıldırım S, Aktaş N. Bir üniversite hastanesinin ameliyathane ve yoğun bakım hemşirelerinde ruhsal durum değerlendirmesi. CÜ Hemşirelik Yüksekokulu Dergisi 2008; 12(2):21-30.

17. Cheng C, Bartram T, Karimi L, Leggat SG. The role of team climate in the management of emotional labour: implications for nurse retention. J Adv Nurs. 2013; 69(12):2812-25. doi: 10.1111/jan.12202

18. Adeniji OG, Akanni AA, Ekundayo OO. Gender difference in emotional labour among nurses in Osun State, Nigeria. Gender \& Behaviour. 2015;13(2):678994.

19. Karimi L, Leggat SG, Donohue L, Farrell G, Couper GE. Emotional rescue: the role of emotional intelligence and emotional labour on well-being and job-stress among community nurses. J Adv Nurs. 2014;70(1):17686. doi: 10.1111/jan.12185

20. Mann S, Cowburn J. Emotional labour and stress within mental health nursing. J Psychiatr Ment Hlt. 2005;12(2):154-62.

21. Dogan A, Sigri U. Emotional labour: A study on nurses. The Journal of Human and Work. 2017;4(2):113-26. doi: $10.18394 /$ iid. 342620

22. Baksi A, Arda Sürücü H. Is spirituality an important variable as the predictor of emotional labour for 
nursing students?. Nurse Educ Today. 2019;79:135-41. doi:10.1016/j.nedt.2019.05.025.

23. Baksi $A$, Arda Sürücü $H$. Factors playing a role in the development of emotional labor behavior of clinical nurses. Perspect Psychiatr C. 2020. doi:10.1111/ppc.12486.

24. Degirmenci S. Developing the scale of emotional labor behavior for nurses [PhD Thesis]. İstanbul: İstanbul University; 2016.

25. Goldberg, D., \& Williams, P. (1988). General health questionnaire.

26. Kılıç C. Genel sağlık anketi: Güvenilirlik ve geçerlilik çalışması. 1996.

27. Hair J, Black WC, Babin BJ, Anderson ER. Multivariate data analysis. 7th ed. Upper Saddle River, NJ: Pearson Education; 2010.

28. Tarhan G, Kılıç D, Yıldız E. Hemşirelerin mesleğe yönelik tutumları ile mesleki profesyonellikleri arasındaki ilişkinin incelenmesi. Gülhane Tıp Dergisi. 2016;58(4):411-16.

29. Çelik S, Ünal Ü, Saruhan S. Cerrahi kliniklerde çalışan hemşirelerin mesleki profesyonelliklerinin değerlendirilmesi. Florence Nightingale Hemşirelik Dergisi. 2012; 20(3):193-99.

30. Karamanoğlu AY, Özer FG, Tuğcu A. Denizli ilindeki hastanelerin cerrahi kliniklerinde çalışan hemşirelerin mesleki profesyonelliklerinin değerlendirilmesi. Fırat Tıp Dergisi. 2009;14(1):12-17.

31. Dikmen $Y$, Yönder $M$, Yorgun S, Usta YY, Umur S, Aytekin A. Hemşirelerin profesyonel tutumları ile bunu etkileyen faktörlerin incelenmesi. Anadolu Hemşirelik ve Sağlık Bilimleri Dergisi. 2014;17(3):158-64.

32. Durmuş $\mathrm{S}$, Günay $\mathrm{O}$. Hemşirelerde iş doyumu ve anksiyete düzeyini etkileyen faktörler. Erciyes Tıp Dergisi. 2007;29(2):139-46.

33. Dede $\mathrm{M}$, Çınar S. Dahiliye yoğun bakım hemşirelerinin karşılaştıkları güçlükler ve iş doyumlarının belirlenmesi. Maltepe Üniversitesi Hemşirelik Bilim ve Sanatı Dergisi. 2008;1(1):3-14.

34. Özkan G. Çağrı merkezlerinde duygusal emek ve örgütsel iletişim. Selçuk İletişim. 2013;7(4):64-80.

35. Kaya ŞD, Yüceler A, Uludağ A, Karadağ Ş. Hasta ilişkilerinde tıbbi sekreterlerin duygusal emek ve iletişim becerilerinin nitel olarak değerlendirilmesi. SDÜ Vizyoner Dergisi. 2017;8(19):62-76.

36. Delgado C, Upton D, Ranse K, Furness T, Foster K. Nurses' resilience and the emotional labour of nursing work: An integrative review of empirical literature. Int J Nurs Stud. 2017;70:71-88.

37. Karim J, Weisz R. Emotions at work: The role of emotional Intelligence and emotional labor in predicting work-family conflict, psychological distress, and life satisfaction. IJASS. 2011;4(3):29-44.

38. Huang ME, Wu ZQ, Tang GQ. How does personality relate to mental health in service industry setting? The mediating effects of emotional labor strategies. Acta Psychol Sin. 2010;42(12):1175-89. (Abstract)

39. Altınöz Ü, Demir S. Yoğun bakımda çalışan hemşirelerde çalışma ortamı algısı, psikolojik distres ve etkileyen faktörler. Psikiyatri Hemşireliği Dergisi. 2017;8(2):95-101.

40. Kinman G, Leggetter S. Emotional labour and wellbeing: What protects nurses?. Healthcare Basel. 2016;4(89):1-12.

41. Van Mol MM, Kompanje EJ, Benoit DD, Bakker J, Nijkamp MD. The prevalence of compassion fatigue and burnout among healthcare professionals in intensive care units: A systematic review. PloS One. 2015;10(8):1-22. 